\title{
A new species of Ophiomisidium (Echinodermata: Ophiuroidea) from the continental shelf and slope off southern Brazil
}

\author{
Michela Borges* $*^{\ddagger}$, Ana Maria G. Monteiro ${ }^{\dagger}$ and A. Cecília Z. Amaral* \\ *Departamento de Zoologia, Instituto de Biologia, Universidade Estadual de Campinas (UNICAMP), CP 6109, \\ 13083-970, Campinas - SP, Brazil. 'Departamento de Zoologia, Universidade Estadual Paulista (UNESP), \\ CP 136, 15001-970, São José do Rio Preto-SP, Brazil. \\ ${ }^{\ddagger}$ Corresponding author, e-mail: michela_borges@yahoo.com.br
}

\begin{abstract}
A new species of Ophiomisidium is described and regards about reproduction are presented. It is the first species in the genus to posses, apparently, a brooding development. Very few specimens of species of Ophiomisidium have previously been collected, but over 3000 specimens of the new species were collected on the continental shelf and slope (60-810 m depth) off southern Brazil. They were obtained during the REVIZEE Programme, the first extensive surveys to examine Brazilian ophiuroids from depths greater than $200 \mathrm{~m}$.
\end{abstract}

\section{INTRODUCTION}

Seven species of Ophiomisidium Koehler, 1914 have previously been described. The genus was erected by Koehler (1914) to accommodate the type species Ophiomisidium speciosum Koehler, 1914 in addition to Ophiomusium flabellum (Lyman, 1878) and Ophiomusium pulchellum Wyville Thomson, 1877 described earlier. Although Koehler (1914) assumed that there was a close relationship between Ophiomisidium and Ophiomusium, the two genera are currently referred to different families (Smith et al., 1995). The presence of the second oral tentacle pores opening outside the oral slit distinguishes Ophiomisidium as a member of the Ophiuridae, Lyman, 1865. The genus is characterized by its small size, low number of dorsal disc plates, enlarged first lateral arm plates, and the relatively large size of the first ventral arm plate in comparison to the more distal plates (Lyman, 1882; Koehler, 1914).

Ophiomisidium is a cosmopolitan genus, confined to deep waters. The new species was collected during the first extensive survey of ophiuroids from depths exceeding $200 \mathrm{~m}$ off the Brazilian coast. Large numbers of individuals occurred between 250 and $808 \mathrm{~m}$ depth. Subsequent study of specimens revealed variations in morphology, and close examination also indicated well-developed juveniles. The new species is the first in the genus to possess, apparently, a brooding development. In addition to a description of the new species, observations on morphological variations and reproduction are provided herein.

\section{MATERIALS AND METHODS}

The specimens studied were among those collected by the REVIZEE Programme/ South Score/ Benthos 'Avaliação do Potencial Sustentável dos Recursos Vivos na Zona Econômica Exclusiva' off the states of Rio de Janeiro, São Paulo, Paraná, Santa Catarina and Rio Grande do Sul $\left(24^{\circ} 07.113^{\prime} \mathrm{S}-29^{\circ} 48.500^{\prime} \mathrm{S}\right.$ and $43^{\circ} 46.759^{\prime} \mathrm{W}-$ $\left.49^{\circ} 06.800^{\prime} \mathrm{W}\right)$.

The collections were made during the REVIZEE Programme from December 1997 to March 1998 between 60 and $810 \mathrm{~m}$ depths. The gear utilized included a Van Veen grab, box corer, and dredges.

Altogether, 3763 individuals were collected, and were preserved dried. The disc diameter (dd) of each specimen was measured with a Mitutoyo CD-6'CS digital caliper or with a ZEISS Stemi W6 stereomicroscope ocular micrometer. Specimens were photographed digitally using a KS100 3.0 Program and a ZEISS Stemi SV11 stereoscopic microscope (Marine Biology Laboratory-Zoology Department/UNICAMP) and a scanning electron microscope (SEM) (JEOLJSM-5800 LV $^{\circledR}$ apparatus) at the Institute of Biology/UNICAMP: the dried specimens were coated with gold and mounted on stubs with doublesided adhesive tape.

Specimens are deposited in the Natural History Museum (MHN) of UNICAMP in the Brazilian Ophiuroidea Collection (MHN-BOPH/MB). The holotype and the paratypes are stored dry too.

\section{SYSTEMATICS}

Order OPHIURIDA Müller \& Troschel, 1840

Family OPHIURIDAE Lyman, 1865

Genus Ophiomisidium Koehler, 1914

Ophiomisidium tommasii new species

(Figures 1 \& 2)

\section{Type material}

Holotype: disc diameter (dd) $=3.8 \mathrm{~mm}(\mathrm{MHN}-\mathrm{BOPH} /$ MB-117H)-Station 6659, 24 $20.527^{\prime} \mathrm{S}-43^{\circ} 46.759^{\prime} \mathrm{W}, 505 \mathrm{~m}$, 9 January 1998.

Paratypes: 33 specimens, $\mathrm{dd}=1.35 \mathrm{~mm}$ to $4.0 \mathrm{~mm}(\mathrm{MHN}-$ BOPH/MB-117P)-Station 6659, $24^{\circ} 20.527^{\prime} \mathrm{S}-43^{\circ} 46.759^{\prime} \mathrm{W}$, 505 m, 9 January 1998. 

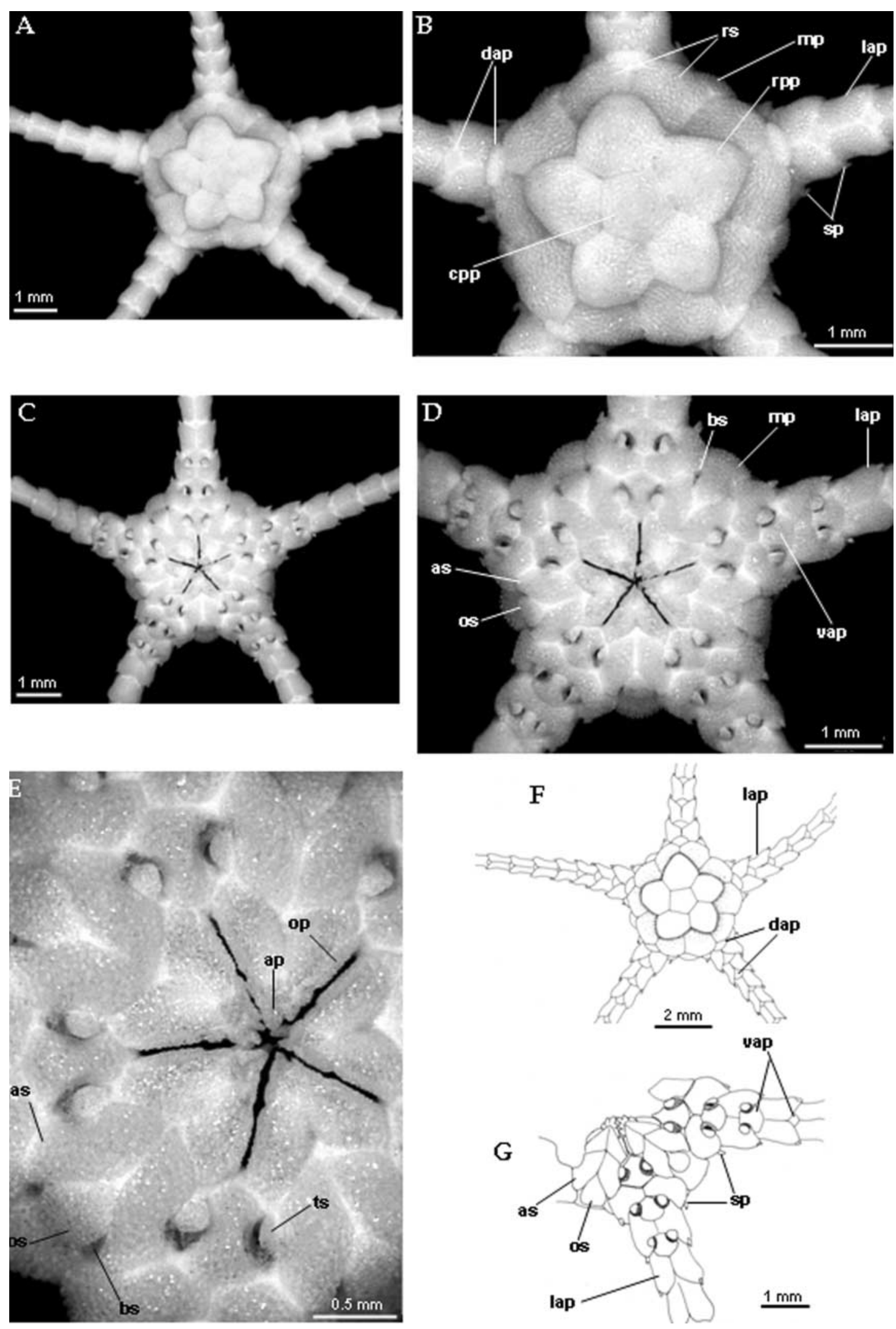

Figure 1. Ophiomisidium tommasii $\mathrm{sp}$. nov.: holotype $\mathrm{dd}=3.8 \mathrm{~mm}$. (A, B, F) Dorsal view; $(\mathrm{C}, \mathrm{D})$ ventral view; (E, G) detail of the oral frame. ap, apical papillae; as, adoral shield; bs, bursal slit; cpp, central primary plate; dap, dorsal arm plate; lap, lateral arm plate; mp, marginal plate; op, oral papillae; os, oral shield; rpp, radial primary plates; rs, radial shield; sp, spines; ts, tentacle scale; vap, ventral arm plate. 
Table 1. Comparison of Ophiomisidium tommasii new species with others of the speciosum group.

\begin{tabular}{|c|c|c|c|c|c|c|c|}
\hline \multirow[b]{2}{*}{ Species/Characters } & \multirow{2}{*}{$\begin{array}{l}\text { Dorsal Surface } \\
\quad \text { (plates) }\end{array}$} & \multicolumn{2}{|c|}{ Shields } & \multirow[t]{2}{*}{ Papillae } & \multirow{2}{*}{$\begin{array}{r}\text { Pores } \\
\mathrm{T}\end{array}$} & \multirow{2}{*}{$\begin{array}{l}\text { Scales } \\
\text { acle }\end{array}$} & \multirow{2}{*}{$\begin{array}{l}\text { Spines (basal } \\
\text { and distal) }\end{array}$} \\
\hline & & Oral & Adoral & & & & \\
\hline $\begin{array}{l}\text { O. pulchellum } \\
\text { Wyville Thomson, } \\
1877\end{array}$ & 2 interradial plates & Small; pentagonal & Long & $1-2$ & 4 & 1 ; rounded & 4 and 3 \\
\hline $\begin{array}{l}\text { O. speciosum } \\
\text { Koehler, } 1914\end{array}$ & 2 interradial plates & Small; pentagonal & Rectangular & 1 & 5 & 1 ; rounded & $\begin{array}{l}3 \text { and } 2 \text { (with } \\
\text { spinules) }\end{array}$ \\
\hline $\begin{array}{l}\text { O. leurum } \\
\quad \text { Ziesenhenne, } 1940\end{array}$ & 2 interradial plates & Small; lozenge & Long & 4 & 5 & $2-3$; oval & 2 and 3 \\
\hline $\begin{array}{l}\text { O. crosnieri } \\
\text { Guille \& Vadon, } \\
1986\end{array}$ & 2 interradial plates & $\begin{array}{l}\text { Pentagonal or } \\
\text { lozenge }\end{array}$ & Trapeze & $2-3$ & 6 & 2; rounded & 2 and 3 \\
\hline $\begin{array}{l}\text { Ophiomisidium tommasii } \\
\text { sp. nov. }\end{array}$ & $\begin{array}{l}1 \text { interradial plate } \\
\text { CPP and RPP }\end{array}$ & $\begin{array}{c}\text { Small; } \\
\text { semi-triangular }\end{array}$ & Well-developed & $2-3$ & 3 & 1; circular & 1 ; sometimes 2 \\
\hline
\end{tabular}

\section{Other examined samples:}

A total of 3729 specimens: MHN-BOPH/MB-116Station $6644,25^{\circ} 45.80^{\prime} \mathrm{S}-45^{\circ} 11.77^{\prime} \mathrm{W}, 485 \mathrm{~m}, 14$ December 1997-3 specimens; MHN-BOPH/MB-117-Station 6659, $24^{\circ} 20.527^{\prime} \mathrm{S}-43^{\circ} 46.759^{\prime} \mathrm{W}, 505 \mathrm{~m}, 09$ January $1998-586$ specimens; MHN-BOPH/MB-118-Station 6660 , $24^{\circ} 17.678^{\prime} \mathrm{S}-43^{\circ} 48.198^{\prime} \mathrm{W}, 314 \mathrm{~m}, 09$ January $1998-1$ specimen; MHN-BOPH/MB-119-Station 6664, $24^{\circ} 26.475^{\prime} \mathrm{S}-44^{\circ} 06.554^{\prime} \mathrm{W}, 505 \mathrm{~m}, 10$ January $1998-2$ specimens; MHN-BOPH/MB-120 - Station 6670 , $24^{\circ} 41.657^{\prime} \mathrm{S}-44^{\circ} 22.645^{\prime} \mathrm{W}, 503 \mathrm{~m}, 11$ January $1998-1$ specimen; MHN-BOPH/MB-121-Station 6679, $25^{\circ} 18.874^{\prime} \mathrm{S}-44^{\circ} 52.516^{\prime} \mathrm{W}, 808 \mathrm{~m}, 12$ January $1998-1850$ specimens; MHN-BOPH/MB-122-Station 6680 , $25^{\circ} 15.064^{\prime} \mathrm{S}-44^{\circ} 52.865^{\prime} \mathrm{W}, 258 \mathrm{~m}, 12$ January $1998-8$ specimens; MHN-BOPH/MB-123 - Station 6680 , $25^{\circ} 15.064^{\prime} \mathrm{S}-44^{\circ} 52.865^{\prime} \mathrm{W}, 258 \mathrm{~m}, 12$ January $1998-1$ specimen; MHN-BOPH/MB-124-Station 6684, $25^{\circ} 43.903^{\prime} \mathrm{S}-45^{\circ} 09.500^{\prime} \mathrm{W}, 511 \mathrm{~m}, 13$ January $1998-1150$ specimens; MHN-BOPH/MB-125-Station 6684, $25^{\circ} 43.903^{\prime} \mathrm{S}-45^{\circ} 09.500^{\prime} \mathrm{W}, 511 \mathrm{~m}, 13$ January $1998-2$ specimens; MHN-BOPH/MB-126-Station 6684, $25^{\circ} 43.903^{\prime} \mathrm{S}-45^{\circ} 09.500^{\prime} \mathrm{W}, 511 \mathrm{~m}, 13$ January $1998-$ 3 specimens; MHN-BOPH/MB-127-Station 6685 , $25^{\circ} 41.827^{\prime} \mathrm{S}-45^{\circ} 11.686^{\prime} \mathrm{W}, 282 \mathrm{~m}, 13$ January $1998-3$ specimens; MHN-BOPH/MB-128 - Station 6689, $27^{\circ} 08.90^{\prime} \mathrm{S}-46^{\circ} 37.70^{\prime} \mathrm{W}, 500 \mathrm{~m}, 18$ January 1998 - 3 specimens; MHN-BOPH/MB-129-Station 6693, $26^{\circ} 41.273^{\prime} \mathrm{S}-46^{\circ} 27.500^{\prime} \mathrm{W}, 430 \mathrm{~m}, 19$ January $1998-82$ specimens; MHN-BOPH/MB-130 - Station 6694, $26^{\circ} 31.269^{\prime} \mathrm{S}-46^{\circ} 34.377^{\prime} \mathrm{W}, \quad 270, \quad 19$ January $1998-1$ specimen; $\quad$ MHN-BOPH/MB-131 - Station 6702, $26^{\circ} 01.50^{\prime} \mathrm{S}-45^{\circ} 59.00^{\prime} \mathrm{W}, 359 \mathrm{~m}$, 21 January $1998-3$ specimens; MHN-BOPH/MB-132 - Station 6705, 25⒌73'S$45^{\circ} 37.32^{\prime} \mathrm{W}, 424 \mathrm{~m}$, 21 January 1998 - 1 specimen; MHNBOPH/MB-152-Station 6777, 26 $51.76^{\prime} \mathrm{S}-46^{\circ} 18.47^{\prime} \mathrm{W}$, 500 m, 13 March 1998-1 specimen; MHN-BOPH/MB154 - Station 6782, 27 $10.18^{\prime} \mathrm{S}-46^{\circ} 46.80^{\prime} \mathrm{W}, 480 \mathrm{~m}, 14$ March 1998-7 specimens; MHN-BOPH/MB-155Station $6782,27^{\circ} 10.18^{\prime} \mathrm{S}-46^{\circ} 46.80^{\prime} \mathrm{W}, 480 \mathrm{~m}, 14 \mathrm{March}$ 1998-1 specimen; MHN-BOPH/MB-156 - Station 6785, $27^{\circ} 29.05^{\prime} \mathrm{S}-47^{\circ} 07.68^{\prime} \mathrm{W}, 510 \mathrm{~m}, 15$ March 1998 - 2 specimens; MHN-BOPH/MB-157-Station 6785, 27 29.05'S- $47^{\circ} 07.68^{\prime} \mathrm{W}, 510 \mathrm{~m}, 15$ March 1998-1 specimen; MHN-

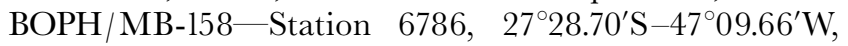
$380 \mathrm{~m}, 15$ March 1998-16 specimens; MHN-BOPH/ MB-159-Station 6790, 27 $49.29^{\prime} \mathrm{S}-47^{\circ} 04.49^{\prime} \mathrm{W}, 500 \mathrm{~m}$, 16 March 1998-1 specimen.

\section{Diagnosis}

Scales and plates swollen, with granular microstructure. Dorsal disc plates consist of central and primary plates, radial shields and one interradial marginal plate; ventral interradial scales absent. Ventral tentacle pores limited to the second buccal tentacle pores and two basal arm segments. One minute arm spine on each arm segment.

\section{Description of Holotype}

Disc. $3.8 \mathrm{~mm}$ diameter, circular and raised above the arms. Dorsally large, swollen primary plates cover most of disc; radial shields encircle margin of disc (Figure 1A,B,F). Central primary plate (CPP) pentagonal; surrounded by larger, subpentagonal radial primary plates (RPP) inserted between radial shields. Radial shields as wide as long, swollen distally and thinner proximally (Figure 1B). Interradial marginal plate extends between each different pair of radial shields and oral shield (Figure 1B,D). Ventral interradius covered by marginal plate, enlarged first lateral arm plates, oral and adoral shields (Figure 1C,D,G). Oral shield small, subpentagonal with rounded borders. Adoral shields considerably larger than oral shield, in contact medially, with lateral indentation accommodating pore of second buccal tentacle (Figure 1D,E,G). Two long, narrow oral papillae on each side of jaw in a narrow strip; the distal is wider than half the lateral space of the jaw, and the slightly narrower proximal occupies the rest of the lateral part. A triangular apical papilla is found at the tip (Figure 1E). Oral papillae may completely close the oral slit. Depression present in the distal region of the jaw. Bursal slit minute, extending between oral shield and the first lateral arm plate (Figure $1 \mathrm{C}-\mathrm{E}$ ).

Arms. Length 1.5 to 2.0 times disc diameter. First dorsal arm plate wider than long, with proximal angle inserting between radial shields, corners rounded distally; distal dorsal arm plates minute, diamond-shaped, absent 

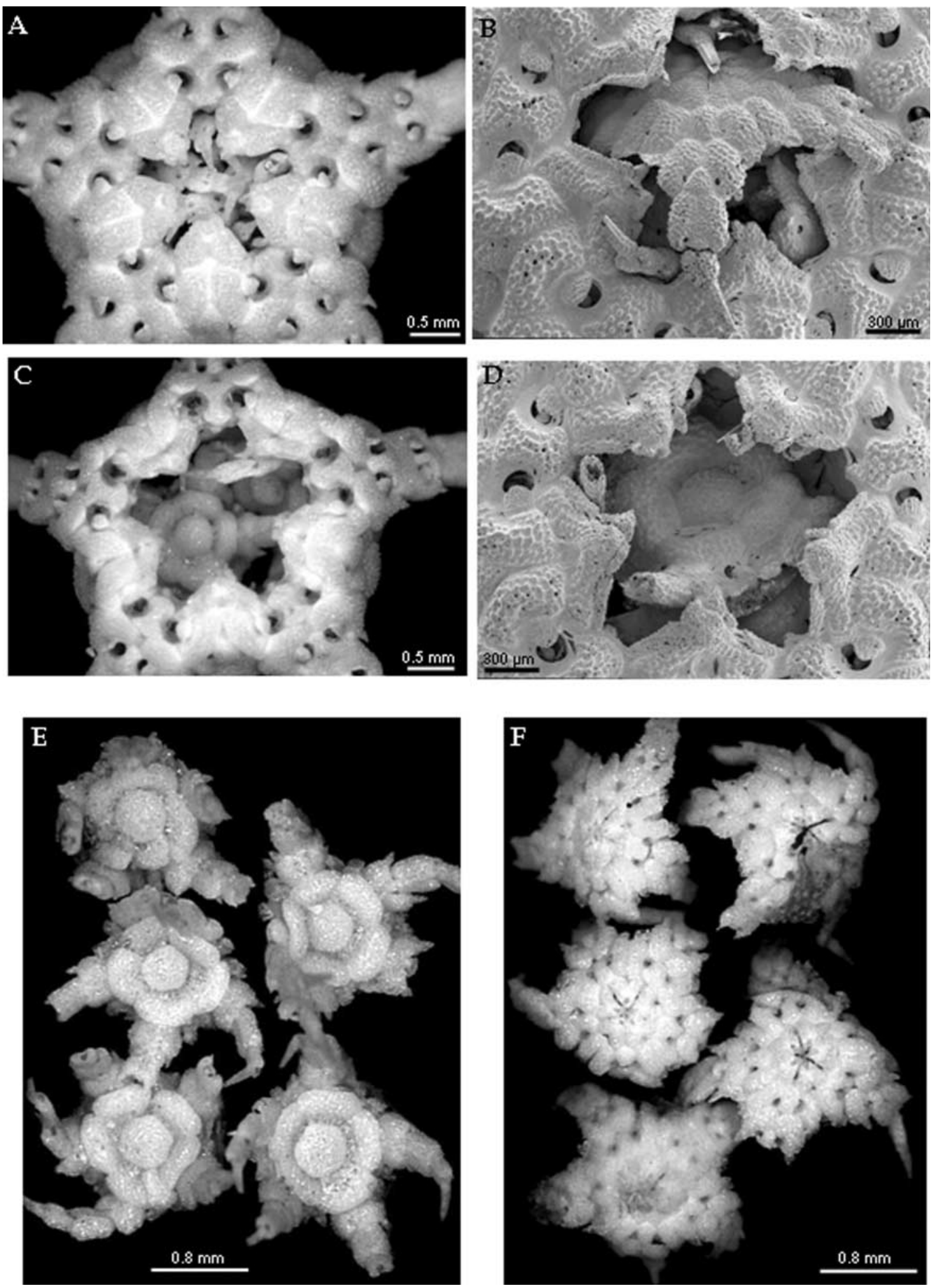

Figure 2. Ophiomisidium tommasii sp. nov. (A-D) Individuals with embryos inside the disc; (E, F) embryos removed from the disc of the adult. 
beyond eighth segment (Figure 1A,B,F). Ventral arm plates present only on basal 5-6 arm segments. Basal 3 ventral arm plates with proximal edges forming an obtuse angle, concave lateral edges accommodating tentacle pores, and broad convex distal edge (Figure 1D,G); more distal ventral arm plates markedly smaller, lozenge-shaped (Figure 1C,D). Lateral arm plates robust, joined dorsally (Figure 1B,F) and ventrally (Figure 1D,G). Three pairs of the tentacle pores, on basal arm segments, each with rounded tentacle scale covering entire pore (Figure 1C,D,G). Single small, adpressed arm spine (Figure 1B) ventrally placed on lateral arm plate.

\section{Morphological variations}

In approximately $16 \%$ of the individuals there were aberrations in the dorsal disc plates, such as alterations in the number and shape of the primary plates and protuberances on the plates, absence of the central plate, and presence of two central plates. In approximately $4 \%$ of the specimens, the number of tentacle pores varied among the different arms of single individuals, presenting one or a pair of additional pores. Arm spines were lacking in some segments because of their fragility or, rarely, two spines were present; the bursal slit was sometimes not observed. The number and shape of the oral papillae varied among specimens, and even on the different jaws of single individuals. In individuals (or jaws) with three lateral papillae: the distal is wider, rectangular and fills almost half of the jaw space; the medial is rectangular and half the size of the distal; the proximal is long and semi-triangular, similar to the infradental. In individuals (or jaws) with two lateral papillae, the distal is wide and fills half the lateral space of the jaw, and the slightly narrower proximal occupies the rest of the lateral part.

\section{Distribution}

Southern Brazil, at depths between 250 and $808 \mathrm{~m}$.

\section{Etymology}

This species name honours Dr Luiz Roberto Tommasi, in recognition of his extensive studies on ophiuroids from Brazil.

\section{Taxonomic relationships and distinguishing characteristics}

Seven species of Ophiomisidium have been described. According to Guille \& Vadon (1986) they fall into two groups. The speciosum group', including O. speciosum Koehler, 1914 (type species), O. pulchellum Wyville Thomson, 1877, O. leurum Ziesenhenne, 1940 and O. crosnieri Guille \& Vadon, 1986, is characterized by a well-developed ventral interradial gap, and widely separated first lateral arm plates that do not extend to the disc margin. The 'flabellum group', including O. flabellum (Lyman, 1878), O. mirabile Smirnov, 1977 and O. irene Fell, 1952, is characterized by a reduced ventral interradial gap and first lateral arm plates that are joined interradially and reach or overlap the disc margin.

The new species is most similar to the 'speciosum' group, but it is somewhat smaller than the other species (Table 1). It has fewer plates on disc and between the radial shields than O. pulchellum, O. speciosum, O. leurum, and O. crosnieri, and fewer tentacle pores. Furthermore, it has fewer plates in the ventral interradius, and fewer and smaller arm spines than the other four species in the group.

\section{BIOLOGY}

\section{Regards about reproduction}

According to Mortensen (1936), about 50\% of the Antarctic and Subantarctic ophiuroids are brooders. Most of the brooders belong to the families Amphiuridae, Ophiacanthidae and Ophiuridae; however, it is not known whether brooding is an intrinsic characteristic of these families or if it is a phenomenon peculiar to the Antarctic species. Relatively few tropical brooder species are known, but their number has been increasing as the reproductive biology of more species in this region is studied (Hendler, 1991).

There are nearly 70 known species of brooding ophiuroids (Hendler \& Tran, 2001), but little is known about their reproductive behaviour, except that most of them are hermaphroditic. Hendler (1979) mentioned that the bursae can be considered as a pre-adaptation for brooding, but it is still not known if there is any structure or specific function for these bursae in brooding ophiuroids. It is possible that metamorphosis in these species is completed precociously, and that most of the brooding period involves the juvenile growth stages. There are indications that embryos of brooding ophiuroids emerge in an advanced stage of development and are larger than recently settled planktotrophic ophiuroids (Hendler, 1991). There has been much speculation that the large size and the mobility of brooding juveniles are the main advantages of this kind of development. However, the fact that some species shelter their embryos and liberate the metamorphosed juveniles does not necessarily mean that nutrients are transferred from adults to juveniles (Hendler, 1975, 1979, 1991).

Ophiomisidium tommasii sp. nov. had a low percentage of individuals with juveniles inside the disc (about 6\%), observed through the oral opening (Figure 2A-D). Some authors (Fell, 1946; Hendler, 1991, 2002), state that the arms of the most well-developed embryos emerge from the parents bursal slit. However, the diminutive dimensions of the species and its bursal slit and the dried preservation made it difficult to determine the exact location of the juveniles, inside the bursa or in the whole disc. No histological analysis can be done due to the dried preservation of the ophiuroids. This is the first record of a possible brooder species in this genus.

Nearly $13 \%$ of the specimens with juveniles inside the disc were examined, verifying that these were well developed compared to adults, varying from 0.8 to $1.0 \mathrm{~mm}$ disc diameter in parents between 2.7 and $3.5 \mathrm{~mm} \mathrm{dd}$. Amphipholis squamata (Delle Chiaje, 1828) also shelter large individuals, about $0.9 \mathrm{~mm} \mathrm{dd}$, for adults with about $2.5 \mathrm{~mm}$ dd. The mechanisms which allow the juveniles to live in the bursae of such small adults and leave through their bursal slits without damaging the juveniles or the parental disc are still unknown (Hendler, 1991).

In this study, the number of brooder juveniles in one adult varied from 1 to 5 , where $8 \%$ of the specimens contained 1 juvenile; $14 \%, 2 ; 22 \%, 3 ; 28 \%, 4$ and 28\%, 5 . In these juveniles it was possible to distinguish six plates on the disc (central and primary) and arms with three segments (Figure 2E,F). Hendler (2002), in a study of the brooding species Ophionereis diabloensis Hendler, 2002, mentioned that 2-7 embryos and not more than one 
juvenile was found in each bursa, varying in size from 0.14 to $1.41 \mathrm{~mm}$ dd, the smallest having one or two arm segments and the largest, nearly 15 . Hendler \& Bundrick (2001) observed up to 11 embryos inside individuals of the species Amphiodia akosmos Hendler \& Bundrick, 2001, in addition to large oocytes in the ovary of individuals with large embryos, suggesting that vitellogenesis occurs during the brooding period. These authors mentioned that brooder embryos had their arms turned to the dorsal region, where the mouth is in contact with the bursal wall, in an easier position for feeding. This position of the embryos was also observed in the species studied here.

According to Byrne (1996), brooding in echinoderms is a characteristic of small species, but not exclusive. According to Hendler (1991) and Hendler \& Bundrick (2001), brooding might be a way of compensating for the disadvantages inherent in their size.

Our thanks to the MMA (Ministério do Meio Ambiente, dos Recursos Hídricos e da Amazônia Legal) and to the State of São Paulo Research Foundation (FAPESP) for financial support. We appreciate the facilities and assistance of the Departamento de Zoologia and the staff of the Laboratório de Microscopia Eletrônica, Instituto de Biologia, UNICAMP. We are deeply grateful to Dr Gordon Hendler and MSc Leonardo Yokoyama for their valuable suggestions.

\section{REFERENCES}

Byrne, M., 1996. Viviparity and intragonadal cannibalism in the diminutive sea stars Patiriella vivipara and P. parvivipara (family Asterinidae). Marine Biology, 125, 551-567.

Fell, H.B., 1946. The embriology of the viviparous ophiuroid Amphipholis squamata Delle Chiaje. Transactions of the Royal Society of New Zealand, 75, 419-464.
Guille, A. \& Vadon, G., 1986. Ophiuridae de l'oceán Indien profond. Indo-Malayan Zoology, 3, 167-188.

Hendler, G.L., 1975. Adaptational significance of the patterns of ophiuroid development. American Zoologist, 15, 691-715.

Hendler, G., 1979. Sex-reversal and viviparity in Ophiolepis kieri, n. sp., with notes on viviparous brittlestars from the Caribbean (Echinodermata: Ophiuroidea). Proceedings of the Biological Society of Washington, 92, 783-795.

Hendler, G., 1991. Echinodermata: Ophiuroidea. In Reproduction of marine invertebrates, vol. 6 (ed. A.C. Giese et al.), pp. 355-511. Pacific Grove: The Boxwood Press.

Hendler, G., 2002. Account of Ophionereis diabloensis, a new species of brittle star, and of $O$. amphilogus, with information on their brooding reproduction and distribution (Echinodermata: Ophiuroidea: Ophionereididae). Proceedings of the Biological Society of Washington, 115, 57-74.

Hendler, G. \& Bundrick, C.J., 2001. A new brooding brittle star from California (Echinodermata: Ophiuroidea: Amphiuridae). Contributions in Science, 486, 1-11.

Hendler, G. \& Tran, L.U., 2001. Reproductive biology of a deepsea brittle star Amphiura carchara (Echinodermata: Ophiuroidea). Marine Biology, 138, 113-123.

Köehler, R., 1914. A contribution to the study of Ophiurans of the United States National Museum. Bulletin of the United States National Museum, 84, 1-173.

Lyman, T., 1882. Report on the Ophiuridae dredged by H.M.S. Challenger, during the years 1873-1876. Report on the Scientific Results of the voyage of H.M.S. Challenger 1873-1876. Zoology, 5, $1-386$.

Mortensen, T., 1936. Echinoidea and Ophiuroidea. Discovery Reports, 12, 199-348.

Smith, A.B., Paterson, G.L. \& Lafay, B., 1995. Ophiuroid phylogeny and higher taxonomy: morphological, molecular and palaeontological perspectives. Zoological Fournal of the Linnean Society, 114, 213-243.

Submitted 27 March 2006. Accepted 1 November 2006. 